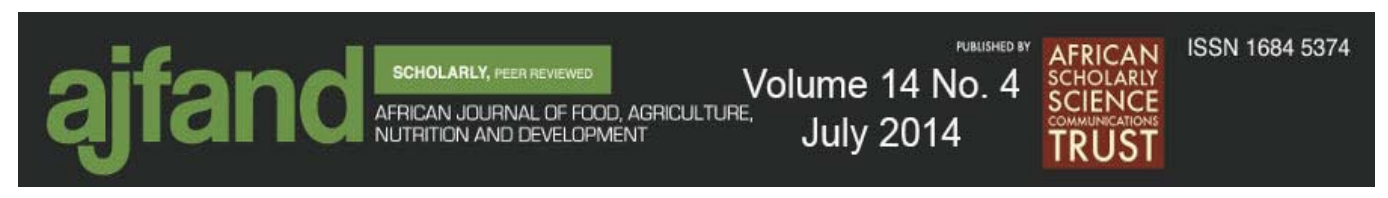

THE POLITICS OF FOOD AND THE FIGHT AGAINST HUNGER: REFLECTIONS AND LESSONS FROM UGANDA

\title{
Kamara $\mathrm{JK}^{1}$ and AMN Renzaho ${ }^{2 *}$
}
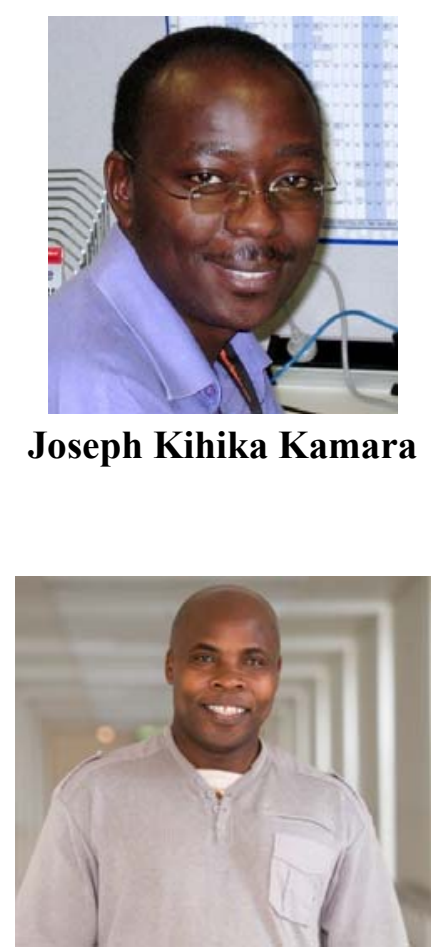

Andre Renzaho

*Corresponding author email: andre.renzaho@,monash.edu

${ }^{1}$ Regional Manager, Africa, International Programming Group, World Vision Australia

${ }^{2}$ ARC Future Fellow and Director; Migration, Social Disadvantage, and Health Programs; Department of Epidemiology \& Preventive Medicine; Monash University $\&$ Senior Fellow- Nutrition, Centre for International Health, Burnet Institute. 


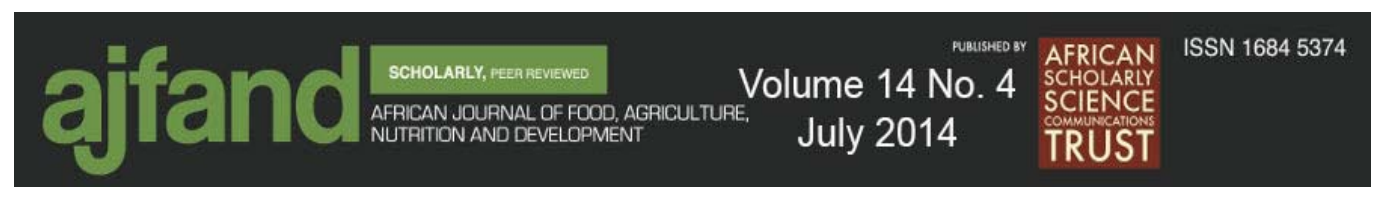

\begin{abstract}
Uganda is regarded as a success story having achieved tremendous economic progress since the end of chronic civil unrest and ethnic conflicts. However, the country faces a host of developmental challenges, especially adult and child hunger in tandem with malnutrition that threatens the core foundations of the impressive economic growth. These challenges have created conditions which led to civil strife especially among the urban poor who are most affected by hunger as opposed to the rural poor who subsist on farming. Out of desperation, some sections of the society use unconventional means to fight hunger; their frustration is often directed at the established authorities. However, factors that precipitate hunger in Uganda are poorly understood. This paper examines how Ugandan politics is being reshaped by the geopolitics of food. The objective is to provide a critical analysis of factors associated with food insecurity for the growing urban population and demonstrate that the Ugandan Government can do better to address the increasing food prices and the high cost of living. The triggers of the 2011/2012 riots in urban areas and the adequacy of the government's response will be discussed. The impact of various factors such as international food markets, population growth and increasing demands for biofuel, on the rising food and fuel prices, will be examined. The paper also reviews other forces driving food insecurity including changes in the weather patterns, the growing middle class, the impact of government policies as well the role of increased urbanisation. The paper concludes that food insecurity for the growing Ugandan population is a threat that can no longer be ignored. This paper argues that achieving food security especially for the urban poor, is an effective means of curtailing civil strife, violence and insecurity in Uganda. The government must be proactive in creating a foundation for food independence and national stability.
\end{abstract}

Key words: Food insecurity, politics, Uganda, price 


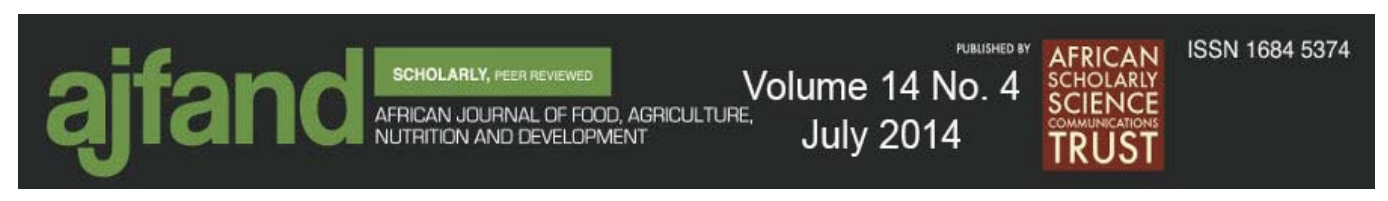

\section{INTRODUCTION}

From an economic growth perspective, Uganda is regarded as successful, having achieved tremendous economic progress since the end of civil unrest in the 1980s [1]. Since 1986, Uganda has recorded an impressive economic growth averaging 6.7\% annually between 1986 and 2008 [2]. Factors identified as contributing to this growth include inflation control, government liberalisation and privatisation policies, foreign direct investment, private sector investment in industries such as construction and service sectors, strong agricultural production, as well as remittances by Ugandans living abroad $[3,4]$. With the recent discoveries of commercial oil deposits, Uganda is likely to continue enjoying strong economic growth if these resources are well managed.

Despite the strong economic growth seen over the last 25 years, Uganda has continually experienced chronic poverty and hunger as evidenced by the Global Hunger Index (GHI). Developed by the International Food Policy Research Institute, the GHI is a tool used to measure and track global hunger by incorporating three interlinked hunger-related indicators: the proportion of the undernourished in the population, the prevalence of underweight children, and the mortality rate of children. Using a 100 point scale (with 0 representing no hunger and 100 being extreme hunger), countries are classified using the following cut-off points: $\leq 4.9$ for "low hunger", 5-9.9 for "moderate hunger"; 10-19.9 for "serious", 20-29.9 for "alarming", and $\geq 30$ for "extremely alarming" hunger problem. In 2011, Uganda's GHI was estimated at 16.7 placing Uganda $42^{\text {nd }}$ out of the 81 countries that were ranked [5]. This indicates a serious hunger problem over the last two decades. Data suggest that, among children under five years old, $16.4 \%$ of them are underweight, $38.7 \%$ are stunted and $6.3 \%$ suffer from wasting or acute malnutrition [6].

However, factors that precipitate child malnutrition and chronic hunger in Uganda are poorly understood. This paper seeks to provide a critical analysis of factors associated with food insecurity and malnutrition for the growing urban population in Uganda. The aim is to examine the relationship between food security and governance. This paper examines the triggers of the 2011/2012 series of protests commonly referred to as the 'walk to work' and the government's response. The paper also examines how factors like international food markets, unfavourable weather conditions, population 


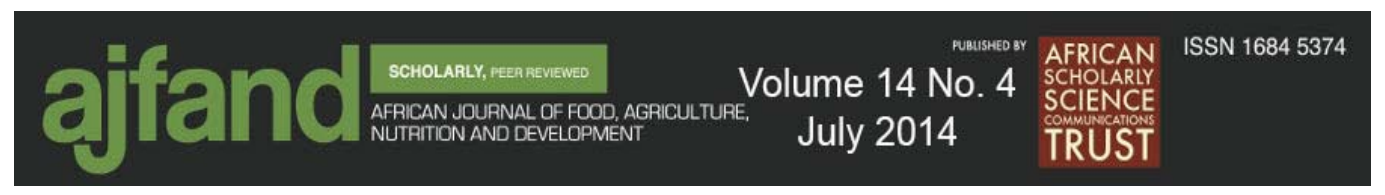

growth, increasing demand for biofuel among others, are driving food and fuel price increases. The paper concludes with a discussion on how food access, especially for the urban poor, could be made more secure.

\section{The 2011/12 urban Ugandan protests}

Evidence suggests that the food and fuel scarcity which led to hikes in food prices had devastating consequences on Ugandans especially the poorest households, who spend about $65 \%$ of their income on food [7]. In April 2011, the situation deteriorated, as a section of the urban population spontaneously responded to the opposition politicians' call to protest under the 'banner' of walking to work in cities and regional towns.

Although the poorest people in Uganda are mostly rural peasant farmers, they did not join the protests possibly because they subsist on their produce; they also have no access to social media which was instrumental in mobilising the urban activism. Rural areas are also sparsely populated hence mobilising crowds at a short notice is difficult. In addition, government representation in rural areas is often by members of the local community perceived as the community's own rather than part of the central government establishment. The large numbers of protesting urban dwellers possibly reflects the severity of food insecurity amongst the urban population.

In an article entitled "Who Will Defend the Rural Poor", the author argues that the emerging urban middle class with reliable access to social media spontaneously heeded the call to protest [8]. A few months earlier, Ugandans had refused to heed the opposition leader's call to protest against the March 2011 general election results, possibly because the results were perceived to be a fair outcome. This paper discusses factors that may disadvantage both rural as well as urban middle class and highlights the complexity in the dynamics of food security among poor Ugandans. Furthermore, this paper discusses the underlying causes of food insecurity and their relationship to the $2011 / 2012$ series of protests in Uganda's urban areas.

\section{Macro-economic imbalance and inflation}

In 2011, Uganda's inflation rate averaged $18.8 \%$, increasing from $4.1 \%$ in 2010 . The trade deficit increased from $9.6 \%$ to $10.8 \%$ of GDP due to excessive government spending during the 2011 elections, as well as an expansionary fiscal policy driven by an increase in energy subsidies [9]. In addition, high import costs due to high fuel 


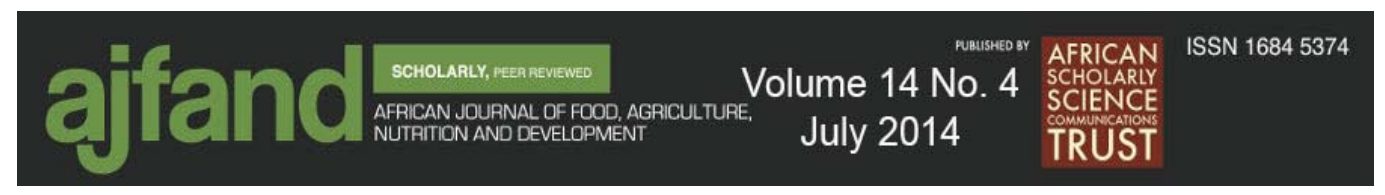

prices exacerbated the devaluation of the Ugandan shilling. The Organisation for Economic Cooperation and Development (OECD) estimates that by the end of 2011, Uganda had a budget deficit of $11.2 \%$ of GDP due to poor economic management [9]. The high inflation and trade deficit cascaded to food markets where retail prices of basic commodities significantly increased (Table 1). This was aggravated by the poor cropping season which affected the quantities of harvested crops and their resulting availability on the market. Earlier, between 2007 and 2009, there was food inflation of a smaller magnitude (Table 1).

Table 1 presents the average price variations of selected commodities between 2007 and 2011. The prices varied across the years but in 2011, Uganda recorded the highest food retail prices, causing civil unrest. The alternative government leaders took advantage of the situation and mobilised citizens for protests. Various sections of the urban population such as traders pressured by high import costs heeded the call and closed their shops. These were followed by taxi drivers protesting against the high fuel costs. Teachers and lecturers in public universities also joined the protest demanding a raise in salary to cope with the rising cost of living [10].

\section{The globalisation of food markets}

Although the largest proportion of Uganda's population subsists on agriculture, food security is interlinked with the international food markets because some of the food is imported. International food markets such as the Goldman Sachs Commodity Index are increasingly becoming dominant in trading and speculating of global food prices [11]. After the 2008 global credit crush, these speculative businesses flourished as a result of trading food because traditional tradeable commodities like real estates were less profitable. Speculation in food trade led to the rapid increase of global prices of commodities like wheat and other cereals. The Minneapolis Grain Exchange became the supreme price-setter for North America's globally consumed wheat [12]. More than half of the high protein hard red spring wheat used in bakeries all over the world was from North America [11].

International markets had an influence on Uganda's soaring food prices, particularly those of high value commodities like wheat and rice which are largely imported. Uganda's annual wheat production has remained below 22,000 metric tonnes since 1990 , even though consumption had risen from 50,000 to 281,844 metric tonnes by 


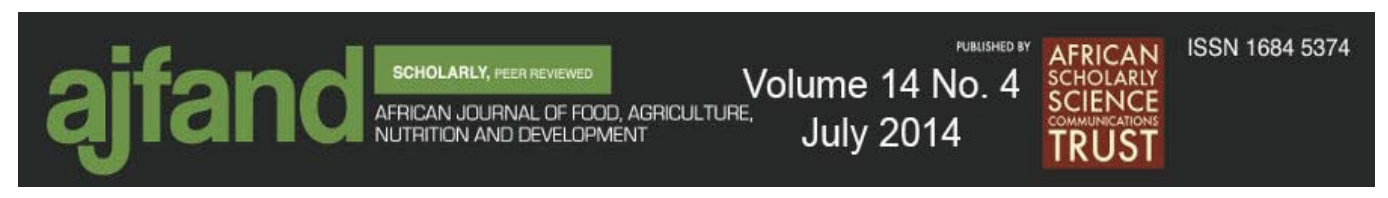

2009 [13]. Since Uganda's wheat consumption was greater than its production, the deficit was mostly imported from USA, Australia, Pakistan, Argentina and Turkey [14]. Therefore, the impact of international markets on Uganda's food security cannot be underestimated.

The rise of piracy along the East African coast, especially between 2010 and 2011, led to increased shipping costs passed on to the consumer. Shipping to East Africa suddenly faced increased insurance costs, ransom payments to pirates to protect ships and crews, and hiring of specialised security companies to provide armed escorts aboard ships to prevent pirate attacks. This resulted in an increase in shipping costs to safeguard the ships as they sailed through the pirate-infested waters to dock at the East African ports. To maintain good profit margins, importers transferred the high shipping costs to the consumers, which in turn inflated the prices of imported commodities such as cereals, especially for urban dwellers. For example, the cost of rice increased by $249 \%$ between 2007 and 2011 (Table1).

Data presented in Table 2 suggest that while the Ugandan population growth per year has remained constant since 1980, the annual maize production has been fluctuating. Production is still insufficient to stem off hunger and support the steady annual population growth of $3.2 \%$. The situation was exacerbated by the fact that maize remains a cash crop, with $14-20 \%$ of the production formally and informally exported to neighbouring countries [15]. In addition, 37\% of maize was procured by the United Nations World Food Program (WFP) for relief operations [16]. Only formal exports are summarised in Table 2, but the amount of maize exported through informal channels is said to be significantly greater [14]. The level of production does not match the growing demand resulting from high population growth as well as the strong demand for maize by the regional market.

In a country where $74.2 \%$ of the population rely on agriculture, there is political support for higher farm produce prices through interventions such as the Plan for Modernisation of Agriculture (PMA), which promotes increased agro processing and marketing. However, this support has encumbrances, including the inability to transform farming from peasantry albeit PMA's operation over a decade. In addition, the urban poor and the middle class will normally resist higher priced farm produce. 


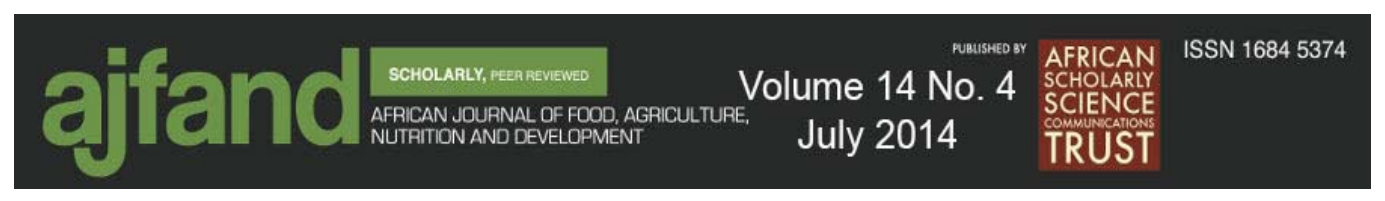

This resistance has set the perfect conditions for the physical confrontation between the government and the urban population.

\section{Rainfall variability}

In Uganda, food production is largely dependent on rain. Drastic rainfall variability affects the underdeveloped agricultural industry. Drought ranks as the single biggest cause of severe food shortages not only in Uganda but in the entire East Africa [17]. In 2011, the Ugandan Government warned that a third of the country faced food shortages because of drought. Previously, the government had projected 15 to $25 \%$ loss in agricultural productivity due to erratic weather [18]. Some scholars have argued that yields of staples especially green banana (matooke) were reduced by $50 \%$ due to drought [19]. However, this claim was not supported by the data in Table 2.

Unfavourable weather patterns such as drought have a direct impact on the country's welfare including reduced purchasing power of staple foods. For example, the per capita production of green banana which contributes to one third of the per capita caloric intake decreased from seventeen to six tonnes per hectare between 1970 and 2011 [20]. The cost of green bananas also increased by 152\% between 2007 and 2011 (Table1). The decrease in per capita production and the soaring price of green bananas occurred even when the average production land area under smallholder production increased from 0.90 to 1.5 hectres [21].

The effects of unfavourable weather patterns observed in Uganda have also been reported in other countries, affecting food availability on global markets and in Uganda. For example, in 2010/11, floods destroyed large acres of crops in Australia leaving a devastating impact on cereal crops [22]. Australia is one of the major exporters of wheat to Uganda [14]. India experienced warmer temperatures in 2008 leading to a drop of more than four million tonnes of wheat production [23]. Russia, one of the largest global exporters of wheat suffered a heat wave in 2010 and lost onethird the national harvest [24]. Scientists predict a temperature increase of one degree Celsius will cause a $10 \%$ decline in grain yields [25]. This is a significant food security threat for net grain importing countries including Uganda. 


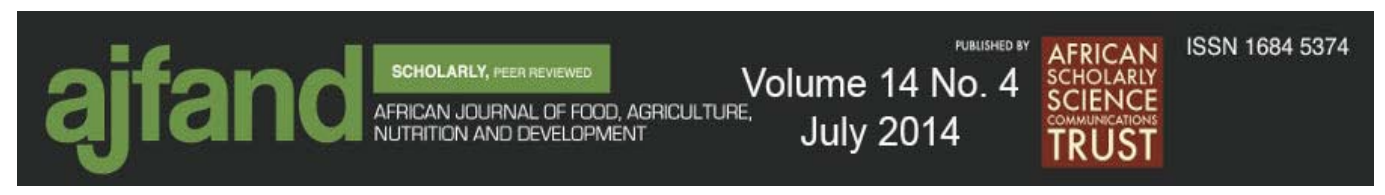

\section{Population growth}

Uganda's population growth rate of $3.2 \%$ is the third highest in the world (Table 2). Between 2008 and 2010, the population increased by $6.6 \%$ but overall food production was estimated to have grown by $2.7 \%$. For example, between 2004 to 2010 , production of rice increased by $25 \%$ implying an annual increment of only $0.24 \%$ [26]. This increase was too small to match the demand and has had a negative impact on pricing (Table 1).

The Ugandan government advocates for a "big Uganda". President Yoweri Museveni insists a big population is necessary for Uganda to defend her territory and wealth [27]. This policy has not been matched with commensurate measures to meet the food needs associated with an accelerated population growth. The policy is also inconsistent with the evidence suggesting high population growth rate of $3.2 \%$ and the high fertility rate of 6.2 children per woman are unsustainable [28]. The investments in agriculture do not correspond with the growing food requirements of the increasing population. For example, only 2.2 million smallholders (with average farm sizes ranging between 0.9 to 1.5 hectares using traditional methods of farming) produce more than $75 \%$ of food for Uganda's population of 33.4 millions [14, 21, 29].

In the next decade, the world will experience intensifed competition for the food driven by population growth with increased per capita consumption among groups with greater purchasing power [6].

\section{The impact of the emerging middle class on food reserves}

The growth of the middle class in Uganda and other countries also underpins the rise in food prices. Uganda's middle class has more than doubled and now represents $18.7 \%$ of the population [30]. Some scholars argue the increase in the standard of living is often accompanied by the preference for better tasting and more expensive food [31]. Like in other countries, the Ugandan middle class is shifting preferences from traditional cereals such as sorghum, millet and maize to processed foods like rice, wheat and related products [32]. Rice is mainly consumed in urban areas and has become a major food as well as a cash crop with an annual average demand growth of $9.5 \%$ since 2000 [33]. 


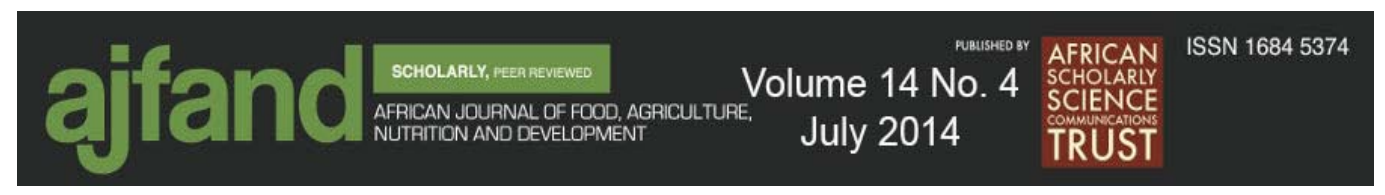

Other middle and low income countries are also experiencing shifts in population demographics with increased demands for processed food. For example, China which is the fastest growing food market doubled its middle class in six years, from 100 million in 2004 to 200 million people in 2010 [34]. Studies estimate that China will have 300 million people with per capita income of more than USD 5000 by 2020 [34]. This will increase demands and eliminate a big proportion of internationally traded food from the global market leaving smaller net grain importing countries like Uganda hungrier.

The growing demand for food in middle income countries requires more creativity such as mass production of meat and dairy products. However, modern livestock farming has had a negative impact on commodity prices because livestock are fed the same grain used for human consumption. To produce a kilogram of grain fed beef, 100,000 litres of water and thirteen kilograms of grain are required [35]. Studies report that up to $37 \%$ of the world's grain harvest is used to produce animal protein and in the United States, livestock consume five times as much grain as is consumed by the human population [36]. Therefore, as more countries transition into middle class, more resources especially in poor countries will be used to meet the increasing demand for food among middle class populations who pay more money for processed food. Although economically beneficial to farmers, this transition diverts grain from humans to livestock .

However, if there is a structural change in demand patterns for staple foods in Uganda due to the growing middle class or increased regional trade, farmers are likely to exploit such new commercial opportunities. These opportunities can be realised if the government translates political support into tangible investment in agriculture.

\section{The stress of increasing global oil prices and biofuel on Uganda}

Between the 2007 and 2011, the average fuel price increased from Uganda shillings 2,200 to 3,600 , representing a $64 \%$ increase [37]. Creative solutions are needed to mitigate the negative consequences associated with increasing prices impacting on the food security especially of the urban poor who buy food.

A decade ago, almost $100 \%$ of Uganda's electricity was hydro generated at the Owen Falls. By 2010, 33.3\% was supplemented by thermal generators consuming 


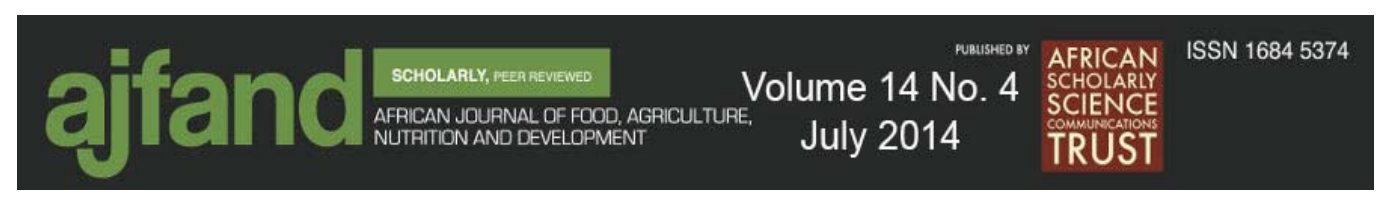

large amounts of subsdised oil [13]. The subsidies were later abandoned after high inflation eroded the purchasing power of the Ugandan shilling and left the cost of food exhorbitantly high in 2011. In addition, the growth of sectors like transport have increased the demand for oil . For example, in 2000 Uganda had only 189,105 registered vehicles compared to 522,654 in 2009 (Figure 1).

Although Uganda's demand for oil remains insignificant in the global market, demands by the new, large, middle class and middle-income countries like Brazil, India, and China exert pressure on supply, leading to a concomitant increase in fuel prices which affect Uganda. The situation is likely to worsen when these countries fully industrialise and move up the 'energy ladder.' China's exponential energy requirements are driven by the demand for energy-intensive products such as motor vehicles.

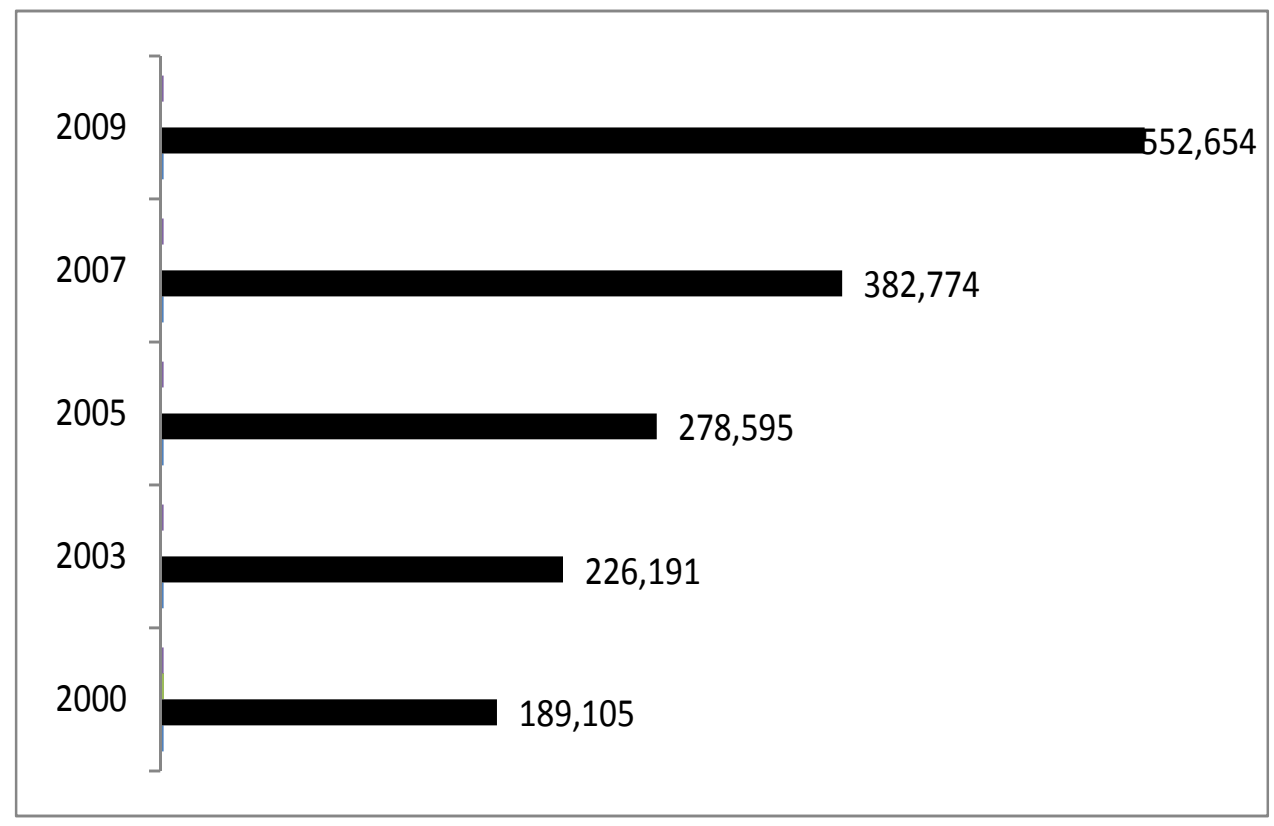

Figure 1: Number of Registered vehicles in Uganda, 2000- 2009

Extracted from Sanya [38]

For example in 1990, China had 6.2 million registered vehicles and a decade later, the number increased to 36 million [39]. To meet this demand, Chinese state- backed companies are extracting oil in almost every oil-producing country. Further growth in 


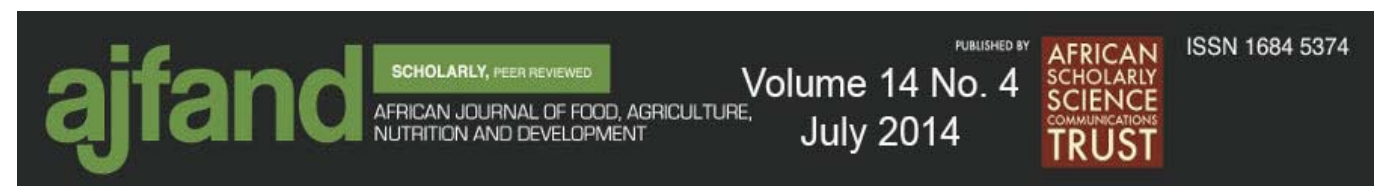

China's energy consumption will have significant implications for the global energy industry [39].

The situation is exacerbated by the lack of an independent agency to regulate the production and oil pricing of the Organisation of Petroleum Exporting Countries (OPEC). In addition, production in some OPEC member states like Iraq, Iran, Libya and Nigeria has been affected by conflicts.

Increasing oil prices have led to the search for alternative and renewable oil sources like biofuel. Uganda's biofuel industry is still in its infancy, piloting multifunctional platforms in Masindi district [40]. Interestingly, using human food to produce biofuel has been on the rise in the European Union (EU), United States of America (USA), Canada, Brazil and China. The increase in demand for crops to produce biofuel led to a $60 \%$ increase in maize prices between 2006 and 2008 [41]. In the 2007/8 crop year, 86 million tonnes of maize were used by the above mentioned countries to produce biofuel [42].

Maize is one of the leading sources of biofuel and also the most common food aid commodity distributed in sub-Saharan Africa. Between 2003 and 2007, Uganda received one million metric tonnes of food aid donated by the USA $(60 \%)$ and $40 \%$ by the EU [43]. This was mainly for the Internally Displaced People's (IDP) camps and drought affected areas in the east and north of the country. A diversion of cereals like maize to biofuel by the major producers like the USA has an impact on the price and availability in countries like Uganda which has been receiving food aid since 1963 [44].

Cassava, Uganda's second staple is under threat because of its potentially high ethanol generation required for biofuel. The bulk of the crop produced is locally consumed; however, it could soon become fodder for the bio fuel industry especially because the second generation biofuel remains costly and more difficult to extract from biomass in the short to medium term compared to the first generation which is predominatly crop-based [45]. Whereas the demand for cassava as a raw material will put more money into the farmers' pockets and improve their well being in the shortterm, it will negatively affect Uganda's food security as more human food is 


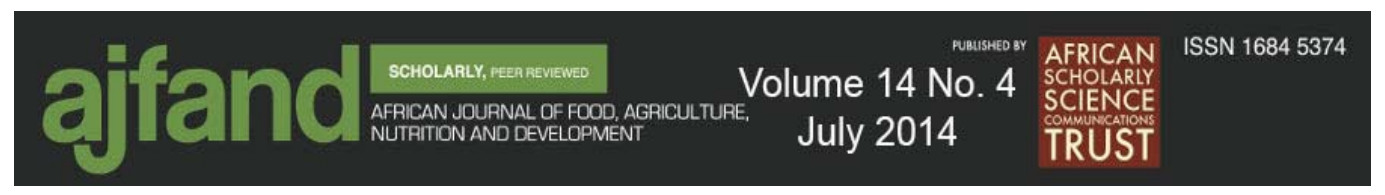

converted into bio fuel. Other food crops fronted for biofuel in Uganda include soybeans, corn, sugarcane and candlenut seed [46].

\section{Urbanisation and food insecurity}

Between 2005 and 2010, Uganda's urban population growth rate was projected at $5.1 \%$ [47]. This was exacerbated by the conflict waged by the Lord's Resistance Army in the north and east of the country, which displaced over two million people into IDP camps, while others sought refuge in urban areas.

Farming continues to suffer from labour shortages as young people move to urban areas for better education and employment opportunities. This shortage has a negative effect on the rural agricultural production. For example, in a study conducted in 1996, farmers attributed the reduction in banana production to reduced labour availability [48]. This could explain the negative growth of $4.1 \%$ in banana production in the same year (Table 2). The rural to urban move would not be a problem if farming in Uganda was mechanised. By failing to modernise agricultural production and create rural opportunities, the government is inadvertently exacerbating rural to urban migration. These urban dwellers squeezed by the soaring cost of living became easy targets for the political opposition's call to "walk to work" protests.

\section{Implications for public health nutrition}

As the economy improves, more people are becoming affluent. However, there are some basic steps that could be taken to minimise the negative impact on Uganda. This section of the paper, discusses possible 'quick wins' that could enable the civil society and government to create long- term solutions.

\section{Strict regime of government financial discipline}

There is an urgent need for a reduction in government expenditure, starting with a reduction in the size of the government. Uganda has a big government with duplicated roles in some departments like ministries and sub ministries known as ministries of State in tandem with those that deputise them, Presidential Advisors, Resident District Administrators and interest groups representatives in Parliament amongst others. 


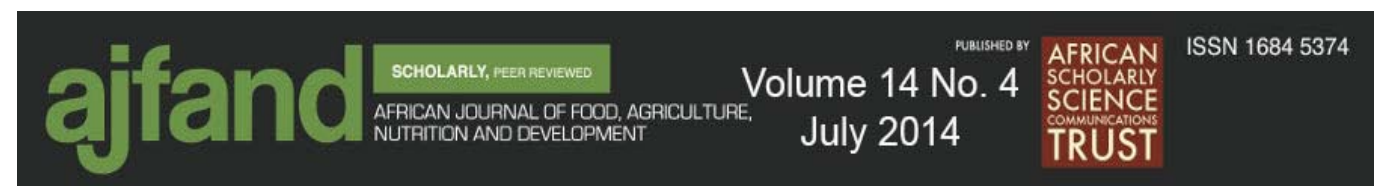

Major government departments that consume large proportions of the budget like the presidency and ministry of defence should be encouraged to refrain from draining the economy. In 2010/11 financial year, the President's office and State house (Presidential residence) were allocated 105.33 billion Ugandan shillings (USD 40.5 millions) out the total national budget of 7.8 trillion Ugandan shillings (USD three billions). By the end of the year, this office had spent 746.6 billion Ugandan shillings or $9.5 \%$ of the national budget [49].

\section{Promote alternative foods and innovation}

Drought tolerant trees and plants such as acacia and cactus which grow wild in Uganda have been a source of food for ancient desert populations like the Aborigines of Australia. These plant species and many others are plentiful in Uganda and could be integrated in the food culture as has been successfully tried out in Ethiopia and Niger $[50,51]$.

Ugandans could also be engaged to farm non-traditional foods such as insects, which have a low environmental footprint but are rich in protein. Insect-based menus are rich in micronutrients often missing from the poor man's meal, which often consist of cereals and tubers. Farming insects would be a game changer in fighting malnutrition. Insects are rich in proteins, vitamins and minerals, and are efficient in converting the food they eat into material that can be consumed by humans [52]. Farming insects is not labour intensive, requires small space and is ecologically sustainable. Specific insects are a delicacy in Uganda albeit being wild and seasonal.

There is also a need to invest in value addition and bio-fortification to increase the nutritional content and shelf life of food. Currently, food from the farm is taken straight to the dinner table. For example, green bananas which have a short shelf life, could be processed, fortified with the required nutrients and packaged to have a longer life span. Agricultural innovations will not only increase farmers' incomes but reduce post-harvest wastage, increase shelf life, and address the malnutrition challenge.

\section{Price regulation on fuel}

Uganda should promote the sustainable use of oil with emphasis on developing a transparent oil industry as the country moves into oil production. The government 


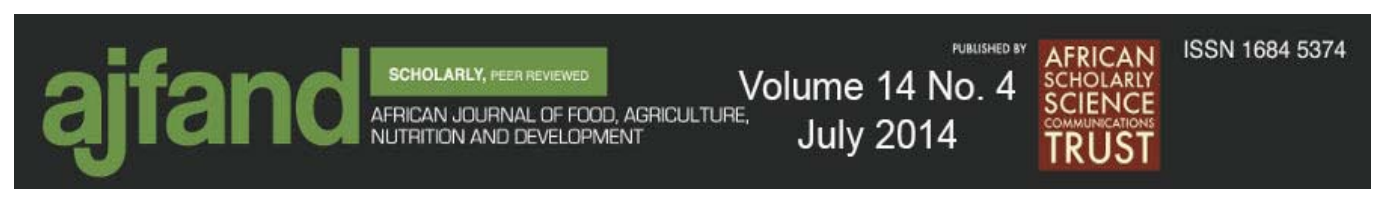

could consider upgrading and expanding the fuel infrastructure to enable bulk stocking and emptying cycles that could be creatively used to control prices. For example in Australia, on weekends, motorists take advantage of reduced prices to fill their tanks until the next weekend when the price drops again. This price drop is related to the cycle of emptying and restocking of reserves to enable consumers cope with the high prices.

\section{Promoting Uganda's comparative advantage and harnessing research}

Uganda has some of the most conducive agricultural conditions such as rich soils and bimodal seasons. Unfortunately, these have not transformed the sector from subsistence. Spending only $3.2 \%$ of the GDP on agriculture undermines the advance of this largest employment sector. There is need for policy dialogue to motivate sustainable production.

\section{Leasing land to foreign governments}

In developing countries, the acquisition of farmland by foreigners seeking to meet the growing food markets in their countries of origin has negative consequences on the food security of poor countries. Africa is lucrative with the most speculative land deals that displace communities from fertile agricultural land to meet the demands of this emerging market [53]. The Ugandan government's approach of leasing land to foreign governments should be based on the evidence of what is practical and contextual.

The practice of leasing land to foreign interest groups has led to civil strife in countries including Madagascar where the government was overthrown for leasing three million acres of land to Daewoo, the South Korean company [25]. In Uganda, the proposal to lease the Mabira Forest to an Indian company for sugar production led to several deaths and was subject to a heated debate [54]. Uganda needs to study how the smallholder farmers can work with and benefit from the foreign agribusinesses' technology, transport and access to better markets.

\section{Establishing strategic food and seed banks}

Uganda could invest in seed and cereal banks to hold excess production and release it in lean seasons, preserve local seeds and maintain a constant supply of seeds without relying on the international seed supplies. Uganda could learn from the Norwegian 


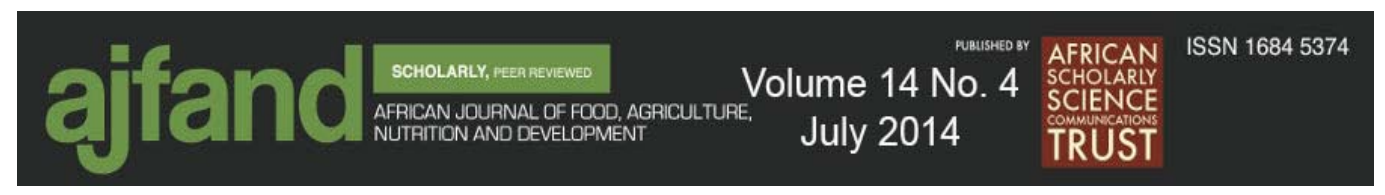

civil society which built an underground facility to store seed samples from all over the world and China's strategic pork reserves created to cushion against price spikes on their preferred meat that is central to their diet [55]. A contextual approach similar to these initiatives would improve the country's food security.

\section{Proactive management of fresh water sources}

Even though Uganda has abundant fresh water sources, watersheds and generous rainfall patterns, the water bodies are slowly diminishing due to unsustainable use. The closed canopy forests that used to cover $20 \%$ of the country, have reduced to $<3 \%$ [56]. This is evidence for the potential total loss of forest cover and watersheds in the nearby future if appropriate policies to contain the high population growth and sustainable usage of natural resources like water and watersheds are not implemented.

\section{CONCLUSION}

Due to the reliance on rain-fed agriculture, food shortages lessen when favourable weather patterns prevail. However, this is temporary if investments in the industry are not accelerated to boost production, processing, marketing and policies that ensure food access for all. Building a food secure future requires extra efforts to increase the productivity of smallholder farmers, enhance nutrition, build resilient communities, and develop sustainable food systems [6].

The protests that started in April 2011 and popularly referred to as 'the walk to work' triggered rolling disobedience by traders, taxi operators, and teachers and became a common occurrence. These are indicators of the disadvantaged segment of the population's concern regarding the high cost of living.

The government must be proactive in creating a foundation for food independence and national stability. Uganda cannot sit on its comparative advantage and wait for foreign assistance to feed her population; it is time to coherently secure the country's food resources for all Ugandans. 


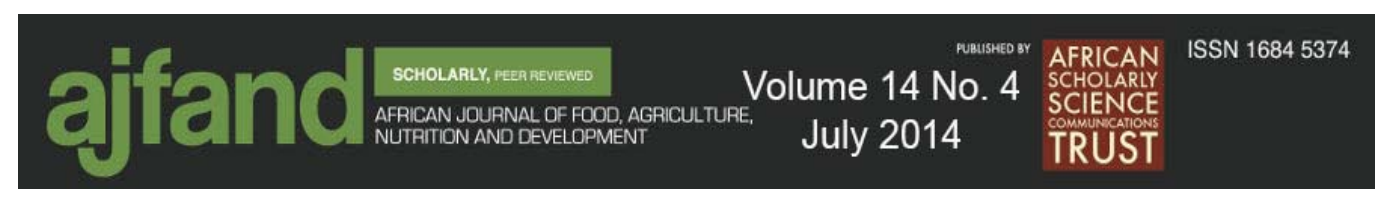

Table 1: Average staple food prices in Uganda between 2007 to 2011

\begin{tabular}{|c|c|c|c|c|c|c|}
\hline \multirow[t]{2}{*}{ Commodity } & \multicolumn{5}{|c|}{ Ugandan Shillings per 100 kilogram bag } & \multirow[t]{2}{*}{ Change } \\
\hline & 2007 & 2008 & 2009 & 2010 & 2011 & \\
\hline Rice & 80,000 & 145,000 & 165,000 & 207,500 & 279,200 & $249 \%$ \\
\hline Beans & 47,000 & 141,300 & 200,000 & 167,100 & 250,000 & $432 \%$ \\
\hline Maize & 30,000 & 95,000 & 61,000 & 147,500 & 174,900 & $483 \%$ \\
\hline Matooke (Green Bananas) & 32,000 & 39,300 & 19,500 & 63,900 & 80,500 & $152 \%$ \\
\hline Cassava & 25,000 & 35,300 & 30,800 & 38,300 & 77,300 & $209 \%$ \\
\hline
\end{tabular}

Extracted from $[15,46,57-58]$ 


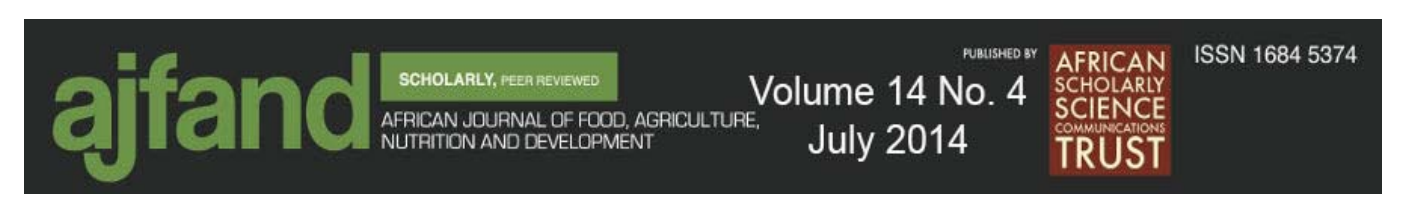

Table 2: Maize and banana production, exports and imports versus population growth in Uganda from 1980 to 2011

\begin{tabular}{|c|c|c|c|c|c|c|c|c|c|c|c|c|}
\hline \multirow[t]{2}{*}{ Year } & \multicolumn{5}{|c|}{ Maize in 1000 metric tonnes a } & \multicolumn{5}{|c|}{ Bananas in 1000 metric tonnes a } & \multicolumn{2}{|c|}{ Population ${ }^{b}$} \\
\hline & Production & Imports & Exports & $\begin{array}{c}\% \\
\text { exported }\end{array}$ & $\begin{array}{c}\text { Growth/ } \\
\text { Year }\end{array}$ & Production & Imports & Exports & $\%$ exported & $\begin{array}{c}\text { Growth/ } \\
\text { year }\end{array}$ & $\begin{array}{c}\mathrm{N} \\
\text { (in 1000) }\end{array}$ & $\begin{array}{l}\text { Growth } \\
\text { Year }\end{array}$ \\
\hline 1980 & 286.0 & 30.0 & & & Ref & 369.0 & 0.0 & 0.0 & $0.0 \%$ & Ref & 12,662 & Ref \\
\hline 1981 & 342.0 & 20.0 & & & $19.6 \%$ & 370.0 & 0.0 & 0.0 & $0.0 \%$ & $0.3 \%$ & 13,049 & $3.1 \%$ \\
\hline 1982 & 393.0 & 50.0 & 20.0 & $5.1 \%$ & $14.9 \%$ & 400.0 & 0.0 & 0.0 & $0.0 \%$ & $8.1 \%$ & 13,448 & $3.1 \%$ \\
\hline 1983 & 413.0 & 4.0 & 30.3 & $7.3 \%$ & $5.1 \%$ & 410.0 & 0.0 & 0.0 & $0.0 \%$ & $2.5 \%$ & 13,866 & $3.1 \%$ \\
\hline 1984 & 338.0 & 8.0 & 40.0 & $11.8 \%$ & $-18.2 \%$ & 400.0 & 0.0 & 0.0 & $0.0 \%$ & $-2.4 \%$ & 14,315 & $3.2 \%$ \\
\hline 1985 & 354.0 & 2.0 & & & $4.7 \%$ & 430.0 & 0.0 & 0.0 & $0.0 \%$ & $7.5 \%$ & 14,801 & $3.4 \%$ \\
\hline 1986 & 322.0 & & & & $-9.0 \%$ & 440.0 & 0.0 & 0.0 & $0.0 \%$ & $2.3 \%$ & 15,328 & $3.6 \%$ \\
\hline 1987 & 357.0 & 0.7 & & & $10.9 \%$ & 460.0 & 0.0 & 0.0 & $0.0 \%$ & $4.5 \%$ & 15,891 & $3.7 \%$ \\
\hline 1988 & 440.0 & 0.0 & & & $23.2 \%$ & 480.0 & 0.0 & 0.0 & $0.0 \%$ & $4.3 \%$ & 16,482 & $3.7 \%$ \\
\hline 1989 & 623.6 & 5.2 & & & $41.7 \%$ & 490.0 & 0.0 & 0.0 & $0.0 \%$ & $2.1 \%$ & 17,088 & $3.7 \%$ \\
\hline 1990 & 602.0 & 7.1 & 26.7 & $4.4 \%$ & $-3.5 \%$ & 560.0 & 0.0 & 0.0 & $0.0 \%$ & $14.3 \%$ & 17,700 & $3.6 \%$ \\
\hline 1991 & 567.0 & 0.0 & 33.1 & $5.8 \%$ & $-5.8 \%$ & 570.0 & 0.0 & 9.8 & $1.7 \%$ & $1.8 \%$ & 18,315 & $3.5 \%$ \\
\hline 1992 & 657.0 & 8.7 & 29.6 & $4.5 \%$ & $15.9 \%$ & 560.0 & 0.0 & 2.0 & $0.3 \%$ & $-1.8 \%$ & 18,936 & $3.4 \%$ \\
\hline 1993 & 804.4 & 46.0 & 160.4 & $19.9 \%$ & $22.4 \%$ & 570.0 & 0.0 & 0.3 & $0.1 \%$ & $1.8 \%$ & 19,562 & $3.3 \%$ \\
\hline 1994 & 850.0 & 13.7 & 100.6 & $11.8 \%$ & $5.7 \%$ & 580.0 & 0.0 & 2.5 & $0.4 \%$ & $1.8 \%$ & 20,193 & $3.2 \%$ \\
\hline 1995 & 913.0 & 33.1 & 69.3 & $7.6 \%$ & $7.4 \%$ & 614.9 & 0.0 & 0.8 & $0.1 \%$ & $6.0 \%$ & 20,831 & $3.2 \%$ \\
\hline 1996 & 759.0 & 78.3 & 81.2 & $10.7 \%$ & $-16.9 \%$ & 590.0 & 0.0 & 3.0 & $0.5 \%$ & $-4.1 \%$ & 21,474 & $3.1 \%$ \\
\hline 1997 & 940.0 & 118.4 & 29.4 & $3.1 \%$ & $23.8 \%$ & 600.3 & 0.0 & 0.1 & $0.0 \%$ & $1.7 \%$ & 22,123 & $3.0 \%$ \\
\hline 1998 & 924.0 & 41.1 & 33.2 & $3.6 \%$ & $-1.7 \%$ & 595.0 & 0.0 & 0.8 & $0.1 \%$ & $-0.9 \%$ & 22,789 & $3.0 \%$ \\
\hline 1999 & 1053.0 & 267.7 & 23.2 & $2.2 \%$ & $14.0 \%$ & 600.0 & 0.0 & 0.8 & $0.1 \%$ & $0.8 \%$ & 23,483 & $3.0 \%$ \\
\hline
\end{tabular}




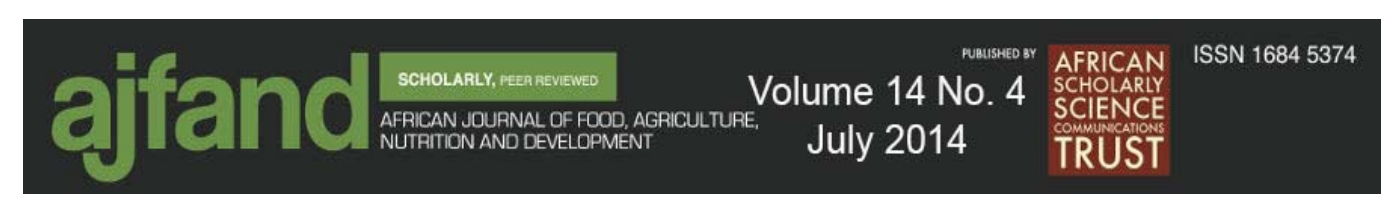

\begin{tabular}{|c|c|c|c|c|c|c|c|c|c|c|c|c|}
\hline 2000 & 1096.0 & 16.7 & 4.2 & $0.4 \%$ & $4.1 \%$ & 610.0 & 0.0 & 1.6 & $0.3 \%$ & $1.7 \%$ & 24,213 & $3.1 \%$ \\
\hline 2001 & 1174.0 & 3.5 & 23.8 & $2.0 \%$ & $7.1 \%$ & 629.7 & 0.0 & 1.1 & $0.2 \%$ & $3.2 \%$ & 24,984 & $3.2 \%$ \\
\hline 2002 & 1217.0 & 29.1 & 41.6 & $3.4 \%$ & $3.7 \%$ & 615.0 & 0.0 & 1.6 & $0.3 \%$ & $-2.3 \%$ & 25,794 & $3.2 \%$ \\
\hline 2003 & 1300.0 & 53.2 & 31.4 & $2.4 \%$ & $6.8 \%$ & 603.3 & 0.0 & 0.1 & $0.0 \%$ & $-1.9 \%$ & 26,642 & $3.3 \%$ \\
\hline 2004 & 1080.0 & 97.4 & 63.0 & $5.8 \%$ & $-16.9 \%$ & 602.4 & 0.0 & 2.2 & $0.4 \%$ & $-0.1 \%$ & 27,522 & $3.3 \%$ \\
\hline 2005 & 1237.0 & 48.2 & 59.8 & $4.8 \%$ & $14.5 \%$ & 562.6 & 0.0 & 2.2 & $0.4 \%$ & $-6.6 \%$ & 28,431 & $3.3 \%$ \\
\hline 2006 & 1258.0 & 40.3 & 81.0 & $6.4 \%$ & $1.7 \%$ & 563.1 & 0.0 & 0.5 & $0.1 \%$ & $0.1 \%$ & 29,370 & $3.3 \%$ \\
\hline 2007 & 1261.8 & 9.4 & 56.3 & $4.5 \%$ & $0.3 \%$ & 524.1 & 0.0 & 1.2 & $0.2 \%$ & $-6.9 \%$ & 30,340 & $3.3 \%$ \\
\hline 2008 & 2314.9 & 22.7 & 24.5 & $1.1 \%$ & $83.5 \%$ & 582.8 & 0.0 & 0.4 & $0.1 \%$ & $11.2 \%$ & 31,339 & $3.3 \%$ \\
\hline 2009 & 2354.7 & 6.6 & 50.6 & $2.2 \%$ & $1.7 \%$ & 591.6 & 1.9 & 0.7 & $0.1 \%$ & $1.5 \%$ & 32,368 & $3.3 \%$ \\
\hline 2010 & 2373.5 & 1.5 & 127.3 & $5.4 \%$ & $0.8 \%$ & 600.0 & 0.0 & 1.6 & $0.3 \%$ & $1.4 \%$ & 33,425 & $3.3 \%$ \\
\hline 2011 & 2551.0 & 17.2 & 55.0 & $2.2 \%$ & $7.5 \%$ & 580.0 & & 0.8 & $0.1 \%$ & $-3.3 \%$ & 34,509 & $3.2 \%$ \\
\hline
\end{tabular}

${ }^{\text {a }}$ Extracted from the FAO Food balance sheets [59]

${ }^{\mathrm{b}}$ Extracted from the World Population Prospects: The 2012 Revision [60]

Note: The amount of foods allocated to food aid is not available. It is estimated that on average 37\% of maize produced is procured by WFP for relief [16]. Data may represent extrapolation of trends rather than real national surveys, caution needed when interpreting such data 


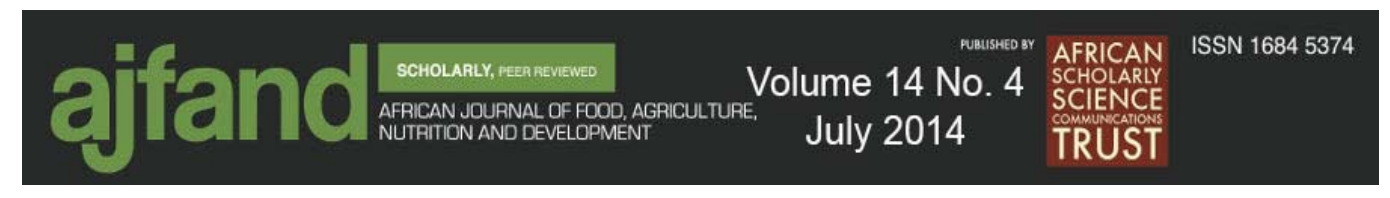

\section{REFERENCES}

1. Okuonzi SA Dying for economic growth? Evidence of a flawed economic policy in Uganda. Lancet, 2004; 364: 1632-1637.

2. Ssewanyana $\mathbf{S}$ and $\mathbf{L}$ Bategeka Chronic poverty and economic growth in Uganda: The role of markets. Chronic Poverty Report, 2007 Pp 1-59.

3. Tangri $\mathbf{R}$ and AM Mwenda President Museveni and the politics of presidential tenure in Uganda. J. Contemp Afr Stud, 2010; 28: 31-49.

4. Feltenstein A and S Sarangi Macroeconomic stabilization and economic growth: The case of Uganda. Afr Dev Rev, 2005; 17: 1-22.

5. von Grebmer K, Ruel TM, Menon P, Nestorova B, Olofinbiyi T, Fritschel $\mathbf{H}$, Yohannes $\mathrm{Y}$, von Oppeln $\mathrm{C}$, Towey $\mathrm{O}$, Golden $\mathrm{K}$ and $\mathrm{J}$ Thompson Global Hunger Index: The challenge of hunger: Focus on the crisis of child undernutrition. Washington, DC: IFPRI, 2010 Pp 1-56.

6. United Nations Development Programme. Africa human development report 2012:Towards a food secure future. Washington, DC: UNDP, 2012 Pp 1-190.

7. Depetris $\mathbf{C N}$, Mulangu $\mathbf{F}$ and $\mathbf{G}$ Porto Food production and consumption trends in sub-Saharan Africa: Prospects for the transformation of the agricultural sector report 2012; New York: UNDP.

8. Mwenda A Who will defend the rural poor?Kampala: The Independent 2011.

9. African Development Bank, Organisation for Economic Co-operation and Development, United Nations Development Programme, and United Nations Economic Commission for Africa. African economic outlook 2012. Available at: http://www.oecd.org/inclusivegrowth/African \%20Economic\%20Outlook\%202012.pdf. Accessed 8 October 2013.

10. Agence de Press Africaine. Uganda's inflation rate now at 21.4\%. Dakar: Agence de Press Africaine 2011. Available at: http://www.apanews.net/photo/en/photo.php?id=156084 Accessed on October 16,2012 .

11. Fazinno D The meaning and relevance of food security in the context of current globolisation trends. J. Land Use \& Envt L, 2004; 19: 435-450.

12. Kaufman $\mathbf{F}$ The food bubble: How Wall Street starved millions and got away with it. New York: Harper's Magazine 2010. 


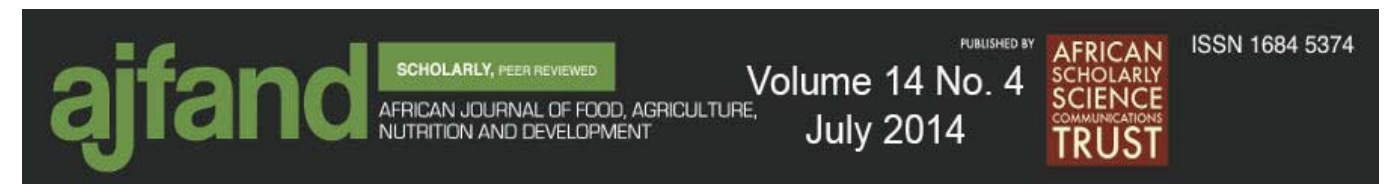

13. Uganda Bureau of Statistics. Statistical abstract. 2010 Pp 61.

14. United States Agency for International Development. Market assessment and baseline study of staple foods Uganda country report, 2010. Washington, DC.

15. Ahmed $\mathbf{M}$ Analysis of incentives and disincentives for maize in Uganda 2012. Technical note series. Rome: FAO.

16. World Food Program. Agriculture and market support in Uganda 20092014: A strategic evaluation brief 2011. Rome: WFP.

17. Terefe HA People in crises: Tackling the root causes of famine in the horn of Africa, 2012. Oslo: Norwegian Agricultural Economics Research Institute.

18. Government of Uganda The state of Uganda population report 2009: Addressing the effects of climate change on migration patterns and women. Kampala: Population Secretariat.

19. Abele $\mathbf{S}$ and $\mathbf{M}$ Pillay Bacterial wilt and drought stresses in banana production and their impact on economic welfare in Uganda: Implications for banana research in East African highlands. J. Crop Improv, 2007; 19: 173191.

20. Masiga CW Disease-resistant bananas are ideal. Kampala: The New Vision 2011.

21. Tenywa MM, Isabirye MI, Lufafa $\mathbf{A}$ and $\mathbf{P}$ Achan Cultural practices and production constraints in smallholder banana based cropping systems of Uganda's lake Victoria basin. Afr Crop Sci. J, 1999; 7:613-623.

22. Alexandratos $\mathbf{N}$ Food price surges: Possible causes, past experience, and longer term relevance. Popul Dev Rev, 2008; 34: 663-697.

23. Aggarwal PK Global climate change and Indian agriculture: Impacts, Adaptation and Mitigation. Ind J Agric Sci, 2008; 78: 911-919.

24. Wegren SK Food security and Russia's 2010 drought. Eurasian Geogr.Econ. 2011; 52: 140-156.

25. Brown $\mathbf{L}$ The new geopolitics of food: From the Middle East to Madagascar, high prices are spawning land grabs and ousting dictators. Welcome to the $21^{\text {st }}$ century food wars. Washington, DC: The Foreign Policy 2011. 


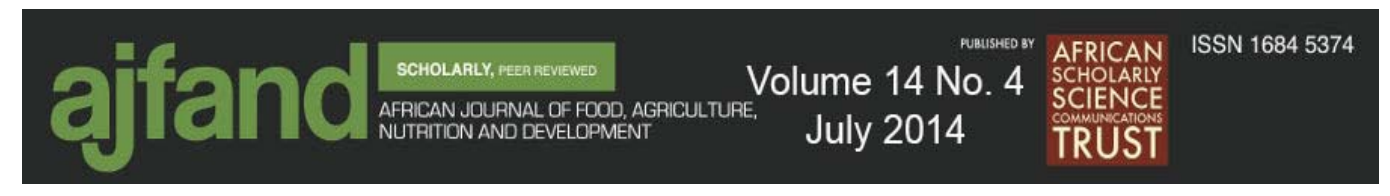

26. The Food and Agricultural Organisation of the United Nations. Rice market monitor, 2011. Rome: FAO. Available at:

http://www.fao.org/economic/est/publications/rice-publications/ricemarketmonitor-rmm/en/ Accessed August 19, 2012.

27. Lutaaya H Why Museveni supports a big population. Kampala: The Sunrise 2010.

28. United Nations Children's Fund The state of the world's children. New York: UNICEF 2012.

29. Salami A, Kamara $\mathbf{A B}$ and $\mathbf{Z}$ Brixiova Smallholder agriculture in East Africa: Trends, constraints and opportunities.2010,Tunis: Africa Development Bank.

30. Africa Development Bank. The middle of the pyramid: Dynamics of the middle class in Africa. 2011, Tunis: Africa Development Bank.

31. Banerjee AV and E Duflo What Is middle class about the middle classes around the world? J Econ Perspect, 2008; 22: 3-28.

32. Cohen MJ and JL Garrett The food price crisis and urban food (in)security. Environ Urban, 2010; 22: 467-482.

33. MAFAP Rice in Uganda: Supporting producers but penalizing consumers. 2013, Kampala: FAO.

34. Lippit VD The Political economy of China's economic reform. Crit Asian Stud, 2005; 37: 441-462.

35. Pimentel D and M Pimentel Sustainability of meat-based and plant-based diets and the environment. Am J Clin Nutri, 2003; 78(3): 660S-663S.

36. Moffitt $\mathbf{C} \mathbf{M}$ Environmental, economic and social aspects of animal protein production and the opportunities for aquaculture. J Aquat, 2005; 13(38): p. 1012.

37. Opio P and P Okudi Trends in fuel prices for the past five years. 2012, Kampala: Uganda Bureau of Statistics.

38. Sanya P The situation of road safety in Uganda. 2010, Kampala:World Bank .

39. Crompton $\mathbf{P}$ and $\mathbf{Y}$ Wu Energy consumption in China: past trends and future directions. Energ. Econ, 2005; 27:195-208.

40. Babagura FK Producing biodiesel to power a multifunctional platform system: Case studies from Africa and Asia. Leusden : Energia 2009 Pp 54. 


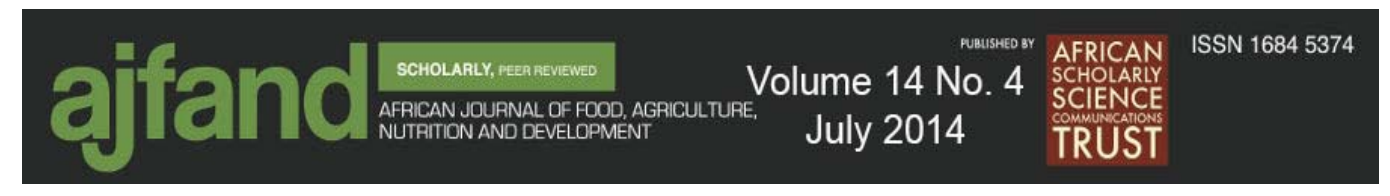

41. Collins $\mathbf{K}$ The role of biofuels and other factors in increasing farm and food prices: A review of recent developments with a focus on feed grain markets and market prospects. 2008, Chicago: Kraft Foods Global Inc.

42. Mitchell DA A note on rising food prices (July 1, 2008). World Bank Policy Research Working Paper 4682. 2008, Washington, DC: World Bank.

43. United States Agency for International Development. Uganda bellmon estimation. 2009, Washington, DC: USAID.

44. Hawksley H Uganda's food aid experiment. London: British Broadcasting Corporation 2011. Available at: http://www.bbc.co.uk/news/world-africa12269677. Accessed September 3, 2011.

45. Miguel A Carriquiry, Xiaodong Du and Govinda R Timilsina Second generation biofuels: Economics and policies. Research working paper 5406 . 2012, Washington, DC: World Bank.

46. Mutenyo F, Kirabo A and R Nansereoko Bridging the food price flux gap: Addressing fundamentals of agricultural sector in Uganda: The food rights alliance and the international food security network. Pdf version avaliable at: http://www.vedcouganda.org/downloads/bridgingfoodgap.pdf Accessed on May 1, 2014.

47. United Nations Human Settlements Program Country programme document 2008-2009: Uganda in UN-HABITAT. Nairobi : UN-HABITAT 2009. Pp 24.

48. Bekunda MA and PL Woomer Organic resource management in bananabased cropping systems of the Lake Victoria Basin, Uganda. Agric Ecosyst Environ, 1996; 59: 171-180.

49. Weinformers Uganda opposition dissatisfied with passed budgetary allocation for 2010/2011financial year. 2011, Kampala: Weinformers Available at : http://www.weinformers.net/2010/09/16/uganda-oppositiondissatisfied-with-passed-budgetary-allocation-for-20102011-financial-year/. Accessed December 11, 2011.

50. Adewusi SR, Falade MS, Oyedapo BO, Rinaudo $\mathbf{T}$ and $\mathrm{C}$ Harwood Traditional and acacia colei seed-incorporated diets in Maradi, Niger Republic. Nutr Health, 2006; 18: 161-177. 


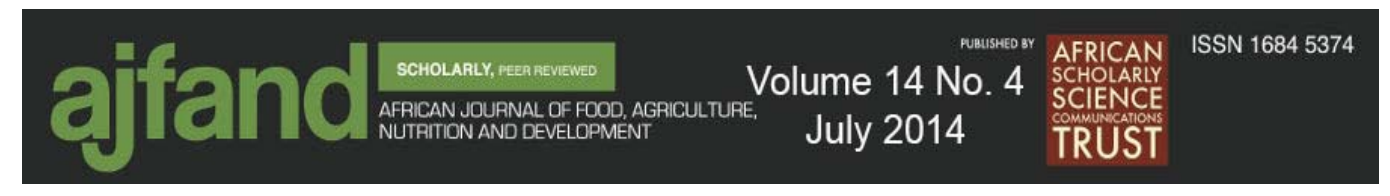

51. Kull CA, Shackleton CM, Cunningham PJ, Ducatillon C, Dufour-Dror J, Esler KJ, Friday JB, Gouveia AC, Griffin AR, Marchante E, Midgley SJ, Pauchard A, Rangan H, Richardson DM, Rinaudo T, Tassin J, Urgenson LS, von Maltitz GP, Zenni RD and MJ Zylstra Adoption, use and perception of Australian acacias around the world. Divers. Distrib, 2011; 17: $822-836$.

52. Durst PB and K Shono Edible forest insects: Humans bite back. 2010, Bangkok: FAO.

53. Borras Jr SM, Hall R, Scoones I, White B and W Wolford Towards a better understanding of global land grabbing: an editorial introduction. $J$ Peasant Stud. 2011; 38(2): p. 209-216.

54. Nampewo $\mathbf{C}$ Saving Mabira rain forest:using public intrest litigation in Uganda to save Mabira forest and other rain forests. B.C. Envtl. Aff. L. Rev. 2013; 40(2): p. 522-553.

55. Keating $\mathbf{J}$ How food explains the world. 2011, Washington, DC: The Foreign Policy.

56. Naughton-Treves L, Alix-Garcia J and CA Chapman Lessons about parks and poverty from a decade of forest loss and economic growth around Kibale National Park, Uganda. Proc Natl Acad Sci, 2011; 108: 13919-13924.

57. Benson T, Mugarura $\mathbf{S}$ and $\mathbf{K}$ Wanda An assessment of the likely impact on Ugandan households of rising global food prices. 2008, Kampala: International Food Policy Research Institute.

58. Mbowa S, Mawejje $\mathbf{J}$ and I Kasirye Increasing food prices and implications on the Ugandan economy. 2012, Kampala: Economic Policy Research Centre.

59. Food and Agriculture Organization of the United Nations FAO STAT. Available at: http://faostat3.fao.org/faostat-gateway/go/to/download/T/*/E. Statistics Division, Rome: FAO. Accessed October 7, 2013.

60. United Nations Population Division World population prospects:The 2012 revision. Data vaialble at: http://esa.un.org/wpp/unpp/panel_population.htm. Accessed October 5, 2013. 